DOI: 10.20472/IAC.2018.040.049

\author{
TOMISLAVA PAVIC KRAMARIC \\ University of Split - University Department of Professional Studies, Croatia
}

IVAN PAVIC

University of Split - Faculty of Economics, Croatia

\title{
DOES BANCASSURANCE AFFECT PERFORMANCE OF NON-LIFE INSURANCE SECTOR - CASE OF EU COUNTRIES
}

\begin{abstract}
:
The aim of this paper is to test the influence of bancassurance as a distribution channel on performance of non-life insurance sector in selected European countries. The analysis refers to 2009 - 2015 period and it is conducted using static panel analysis. Performance measures employed comprise of sales profitability as well as of profitability ratio of technical activity whereas independent variables used in the model include share of bancassurance, market share, gross written premium growth rate, claims growth rate, insurance density, share of premium in GDP, share of reinsurance and number of insurance companies. The results of the analysis in both models reveal that market share prove to be statistically significant determinant of insurance sector performance negatively affecting performance. Furthermore, insurance density has statistically significant and positive influence on performance measured with profitability ratio of technical activity.
\end{abstract}

\section{Keywords:}

bancassurance, non-life insurance industry performance, EU countries, static panel analysis

JEL Classification: G22, L10, O16 